\title{
Loss of Distributed Generation in Case of Fault in Distributing Net
}

\author{
Vladimír Volčko, Žaneta Eleschová, Martin Liška, Miroslava Smitková* \\ Slovak University of Technology, Faculty of Electrical Engineering and Information Technology, Institute of Power and Applied Electrical \\ Engineering, Department of Electrical Power Engineering, Ilkovičova 3, Bratislava SK-81219, Slovakia \\ *Corresponding Author: miroslava.smitkova@stuba.sk
}

Copyright (C) 2013 Horizon Research Publishing All rights reserved.

\begin{abstract}
This paper deals with the $22 \mathrm{kV}$ distribution grid with higher penetration of distributed generation and the possibility of loss of this generation in case of fault. In the first part the reasons of distributed generation growth are shortly explained. For simulation of faults of different parts of distribution grid the model of such distribution grid with substantial amount of distributed generation was created. The second part contents the simulations of two-phase faults in two different power lines of model in order to evaluate and analyze the impact of these faults on distributed generation. The second part focuses on the impacts of short circuit occurred in different feeders of distribution grid on individual power sources and on the feeder with higher penetration of distributed generation.
\end{abstract}

Keywords Smart Grid, Distributed Generation Protection, Distributed Generation Model

\section{Introduction}

Electric Power Research Institute (EPRI) [1] defines present electric power system as system primary comprising large central-station generation connected by a high voltage network to local electricity distribution system which, in turn, serve homes, business and industry. It is also described as one way power system, where electricity flows predominately in one direction using mechanical controls.

The future electric power grid (or Smart Grid) EPRI [1] is defined as a network which still depends on support of large central-station generation, but which includes a substantial number of installations of electric energy storage and renewable generation facilities, both at the bulk power system level and distributed throughout. EPRI [1] also refers to great enhancement of sensory and control capability in the Smart Grid. The Smart Grid can by also described as "both way power system".

Considerable importance in the future electricity generation is given to renewable energy sources and distributed generation. [2] The importance of usage of renewable energy sources results from climate changes as well as fuel diversity, energy security and it is included in the European energy policy (see [3, 4]). Publication [5] also sees the local supply (or distributed generation) as a means to reduce the amount of energy transferred through transmission and distribution lines and as a means to reduce transmission and distribution loses. In Slovakia the development of distributed generation is expected especially in the field of photovoltaic and biomass [6].

Also electric vehicles may be considered as distributed generation and recharging demand profile can affect the load of power system [9].

High penetration of distributed generation does not influence only the control, but also the protection relays. Disconnection of large power in distributed generation due to distance fault could significantly endanger the balance between the electricity production and its consumption.

This paper deals with the possibility of such unselective disconnection of distributed generation in case of fault of $22 \mathrm{kV}$ distribution line. The paper presents partial results from research of the influence of self-sustaining smart regions on power system.

\section{Model Description}

To simulate the fault occurrence in distribution generation the Matlab Simulink environment and SimPowerSystems libraries has been used. The model of distribution grid consists of five $22 \mathrm{kV}$ feeders, fed by $110 \mathrm{kV} / 22 \mathrm{kV}$ transformer with nominal power of 25 MVA. The rest of $110 \mathrm{kV}$ network is modeled as infinite bus with nominal voltage $110 \mathrm{kV}$ and three phase short circuit current $1.32 \mathrm{kA}$. Four of the feeders consist of a line with particular length with electricity load connected at the end of base line. The first feeder is expended and more complex to simulate the fault occurrences and its consequences on protection relays.

The analyzed feeder contains total active load $646 \mathrm{~kW}$ and reactive load $212.2 \mathrm{kVAr}$. This feeder contains also small power sources as a model of distributed generation. 
The distributed generation was modeled by 4 photovoltaic power plants Pv1-Pv4 (each with nominal power of $50 \mathrm{~kW}$ ) and one synchronous generator CG with nominal power of $250 \mathrm{~kW}$ (this generator represents in model electrical source using potential of biomass).

Sources are connected to the feeder in different distances from feeding transformer (Fig. 1). Each source with terminal voltage $400 \mathrm{~V}$ is connected to the feeder through transformer $22 \mathrm{kV} / 400 \mathrm{~V}$. (Fig. 2, Fig. 3)

The $22 \mathrm{kV}$ power grid was simulated as IT system (insulated neutral of feeding transformer).In such system the most common fault - connection of one phase to ground is not short circuit and so increase of the fault current is not significant..

Therefore following three faults were simulated on the model of $22 \mathrm{kv}$ network:

- Phase short circuit fault on line V1 in $10 \%$ of V1 length,

- Two phase short circuit fault on line V2 in $10 \%$ of V2 length,

- Two phase short circuit fault at the end of line V2.

For each fault the short circuit currents of each source (including infinite bus) were evaluated. In the case of short circuit on line V2 the short circuit current flowing through line V1 was also calculated.

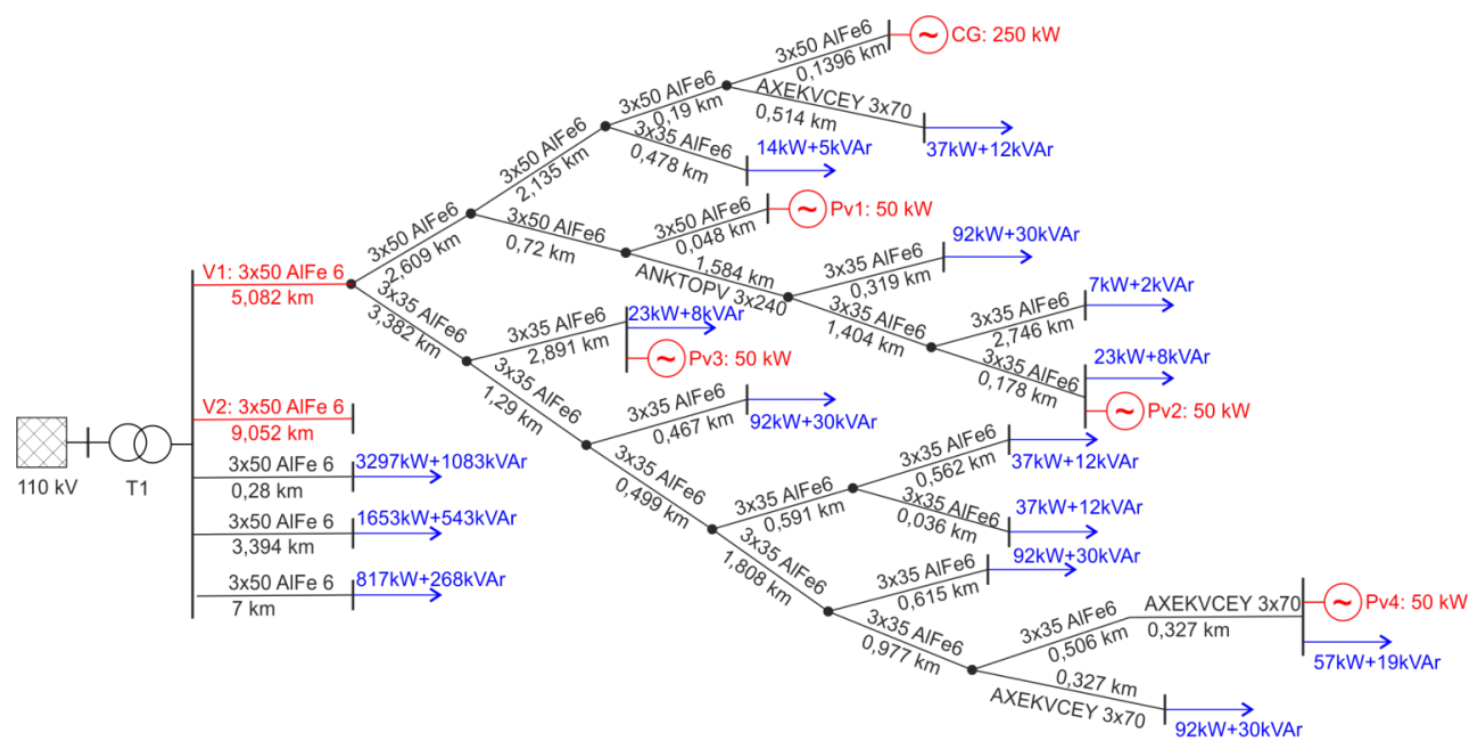

Figure 1. Scheme of distribution network model
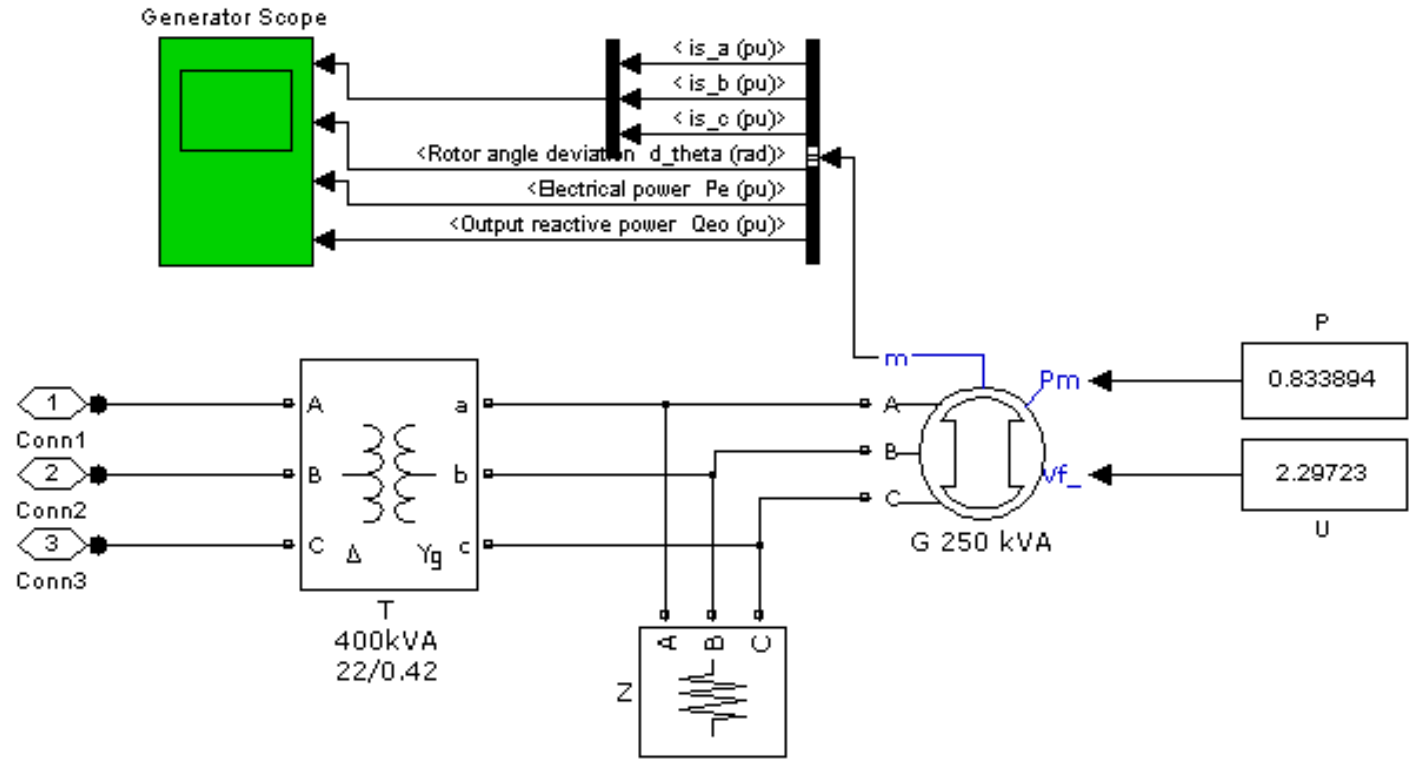

Figure 2. Model of cogeneration unit 


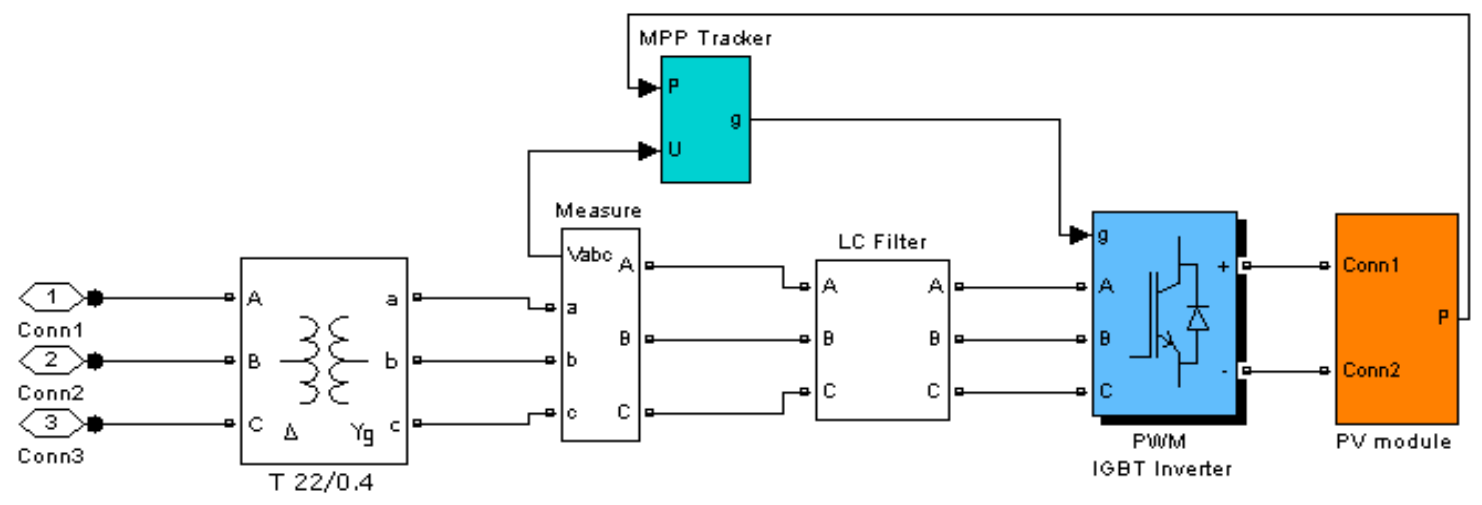

Figure 3. Model of photovoltaic power plant

\subsection{Model of Synchronous Generator}

Since the biomass is the most perspective source of renewable energy in Slovakia, it is also included in the model. One of the methods of conversion of chemical energy of biomass to electrical energy is combined heat and power.

Combined heat and power (CHP) is a power plant generating simultaneously electricity and heat. It is mostly operated as gas engine fed by natural gas or biogas. The synchronous generator producing electricity is powered by the gas engine. According to the energy potential, this source is very perspective in Slovakia and therefore is considered in the model as a part of distributed generation.

The CHP was modelled as a synchronous generator connected to the grid via transformer $22 \mathrm{kV} / 0.4 \mathrm{kV}$ (Fig. 2). As a model of synchronous generator the pressed model of Synchronous Machine Standard with nominal power of $250 \mathrm{kVA}$ and nominal voltage of $400 \mathrm{~V}$ was used. The table (tab. 1) shows the synchronous generator parameters:

Table 1. Project selection matrix rules

\begin{tabular}{|c|c|c|c|}
\hline Parameter & Value & Parameter & Value \\
\hline $\mathrm{X}_{\mathrm{d}}[\mathrm{pu}]$ & 2.84 & $\mathrm{X}_{\mathrm{L}}[\mathrm{pu}]$ & 0.09 \\
\hline $\mathrm{X}_{\mathrm{d}}{ }^{\prime}[\mathrm{pu}]$ & 0.18 & $\mathrm{~T}_{\mathrm{d}}{ }^{\prime}[\mathrm{s}]$ & 0.08 \\
\hline $\mathrm{X}_{\mathrm{d}}{ }^{\prime}[\mathrm{pu}]$ & 0.13 & $\mathrm{~T}_{\mathrm{d}}{ }^{\prime}[\mathrm{s}]$ & 0.019 \\
\hline $\mathrm{X}_{\mathrm{q}}[\mathrm{pu}]$ & 2.44 & $\mathrm{~T}_{\mathrm{q}}{ }^{\prime}[\mathrm{s}]$ & 0.019 \\
\hline $\mathrm{X}_{\mathrm{q}}{ }^{\prime}[\mathrm{pu}]$ & 0.36 & $\mathrm{R}_{\mathrm{S}}[\mathrm{pu}]$ & 0.02594 \\
\hline
\end{tabular}

The active power of synchronous generator was set to $200 \mathrm{~kW}$ with terminal voltage of $400 \mathrm{~V}$. Considered protection of synchronous generator was low voltage circuit breaker with rated current of $360 \mathrm{~A}$ and $\mathrm{B}$ type of characteristic.

\subsection{Model of Photovoltaic Power Plant}

The photovoltaic power plant was modelled as a photovoltaic module connected via IGBT Inverter, LC filter and transformer into the power grid of $22 \mathrm{kV}$ (Fig. 3). A part of the model of photovoltaic power plant is a MPP tracker. The algorithm of the MPP tracker was designed in compliance with [6]. This MPP tracker issues the control of IGBT inverter to maximize the power of PV modules.

In the photovoltaic power plant both can be used naturally commutated invertors and force commutated invertors. In the model only force commutated invertors (IGBT) are considered. The current harmonics generated by the inverter multiples of $2 \mathrm{kHz}$ are filtered by the LC filter.

The PV module has a non-linear V-I characteristic. The nonlinearity of such module is achieved by controlling the voltage source (shown in the Fig. 5). The terminal voltage of PV module depends on its load current. The terminal voltage of PV module is controlled by this current with respect to the nonlinear shape of V-I characteristic. The DC voltage source (Fig. 5) is intended for transients after the simulation start. DC voltage source is disconnected in time of $0.2 \mathrm{~s}$ by breaker. The V-I characteristic of PV panel generated by PV module is shown on Fig.4.

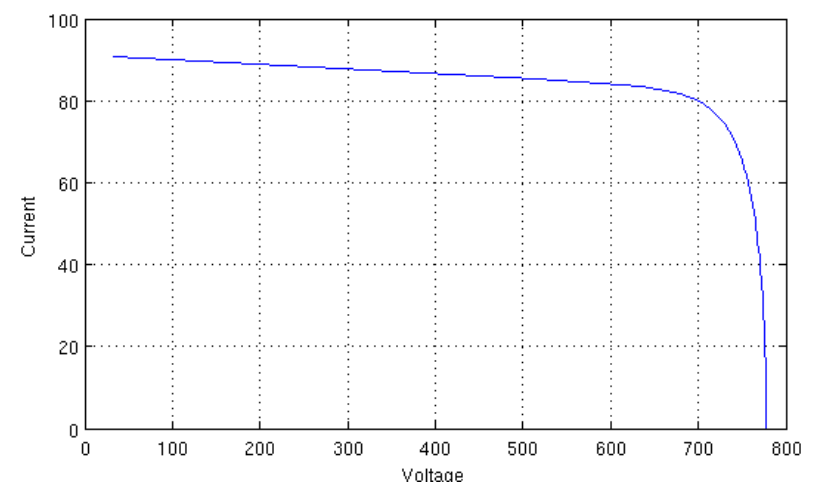

Figure 4. Current-voltage characteristic of modelled photovoltaic panel

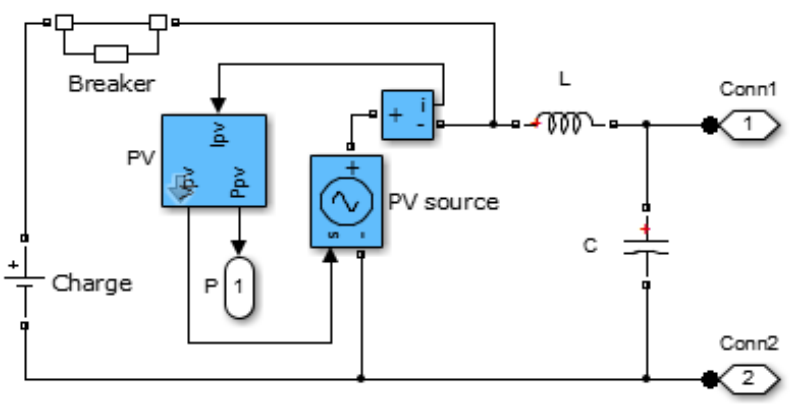

Figure 5. Model of Photovoltaic Panel 
The equivalent circuit of PV panel is shown in Fig. 5. Calculation of PV module (in Fig. 5) is designed according to this equivalent circuit.

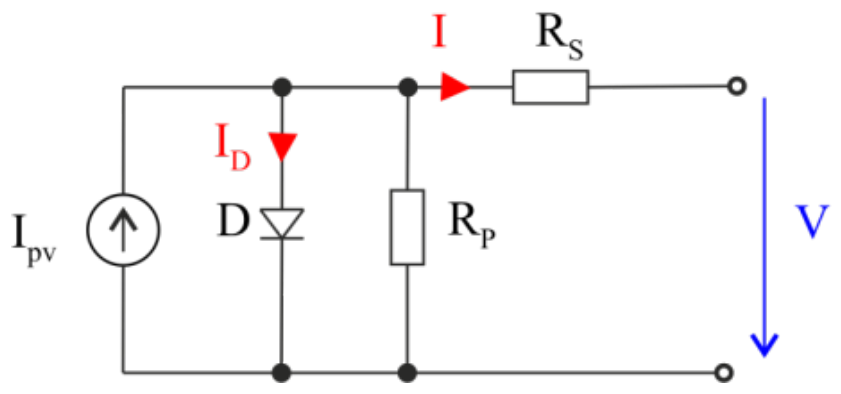

Figure 6. Equivalent model of Photovoltaic Panel [7]

According to Fig. 6 the following equations can by written:

$$
\begin{gathered}
V=V_{d}-R_{s} I \\
I=I_{p v}-I_{d}-\frac{V_{d}}{R_{p}} \\
I_{d}=I_{\text {sat }} e^{\frac{V_{d}}{V_{T}}-1}
\end{gathered}
$$

Where:

$\mathrm{I}_{\mathrm{d}}-$ diode current $[\mathrm{A}]$

$\mathrm{V}_{\mathrm{d}}$ - diode voltage $[\mathrm{V}]$

$\mathrm{V}_{\mathrm{T}}$ - temperature voltage $[\mathrm{V}]$

$\mathrm{R}_{\mathrm{s}}$ - series resistance $[\Omega]$

$\mathrm{R}_{\mathrm{p}}$ - shunt resistance $[\Omega]$

Because of photovoltaic panel characteristic displayed on fig. 4, the inverter cannot be protected with fuses or low voltage circuit breaker. Therefore the overcurrent protection relay was used with release current $20 \%$ higher than nominal current of inverter.

\section{Simulations Results}

The point of the short circuit faults was placed on the both feeders (line V1 and line V2) at the same distance $10 \%$ length of base line form the transformer $110 \mathrm{kV} / 22 \mathrm{kV}$. The faults occurred at the time $2 \mathrm{~s}$ after the simulation start (the time delay is needed to stop the oscillations and to stabilize the sources). During simulations currents of all sources were monitored and protections reaction evaluated possibilities.

The simulations were focused on the following faults:

- Two phase short circuit fault in the base line V1. The fault occurs at the time $2 \mathrm{~s}$ and base line was disconnected after $0.2 \mathrm{~s}$,

- Two phase short circuit fault in the base line V2 started at the time $2 \mathrm{~s}$ and failed line was disconnected at the time $2.2 \mathrm{~s}$.

\subsection{Fault on Line V1}

In this case a short circuit occurred on the base line V1 between phases L1 and L2 in 10\% length of base line $(0.508 \mathrm{~km})$. The comparisons of nominal current (In), RMS short circuit current of each phase (IkL1 - IkL3) and maximum peak value of short circuit current of each source (photovoltaic $1-4$, cogeneration unit and transformer) is shown in Tab. 2.

Table 2. Short circuit currents

\begin{tabular}{|c|c|c|c|c|c|c|}
\hline & PV1 & PV2 & PV3 & PV4 & CHP & $\begin{array}{c}\text { Transform } \\
\text { pr }\end{array}$ \\
\hline $\mathrm{I}_{\mathrm{n}}[\mathrm{A}]$ & 72.1 & 72.1 & 72.1 & 72.1 & 360 & 3600 \\
\hline $\mathrm{I}_{\mathrm{kL} 1}[\mathrm{~A}]$ & 89.85 & 89.82 & 89.92 & 89.85 & 826.68 & 6002 \\
\hline $\mathrm{I}_{\mathrm{kL} 2}[\mathrm{~A}]$ & 73.95 & 73.94 & 73.99 & 73.9 & 488.66 & 5876 \\
\hline $\mathrm{I}_{\mathrm{kL} 3}[\mathrm{~A}]$ & 45.38 & 45.4 & 45.44 & 45.53 & 930.75 & 159 \\
\hline $\mathrm{I}_{\mathrm{p}}[\mathrm{A}]$ & 210.9 & 218.31 & 231.27 & 262.92 & 2746.3 & 12413 \\
\hline
\end{tabular}

From the Tab. 2 it can be seen, that the currents supplied by each photovoltaic power plant during the fault were only $24 \%$ over the nominal current. The tripping current of inverter protection relay is set to 1.2 times the nominal current. Therefore the fault on the power line V1 could cause disconnection of all connected photovoltaic power plants which results to loss of all power from distributed generation.

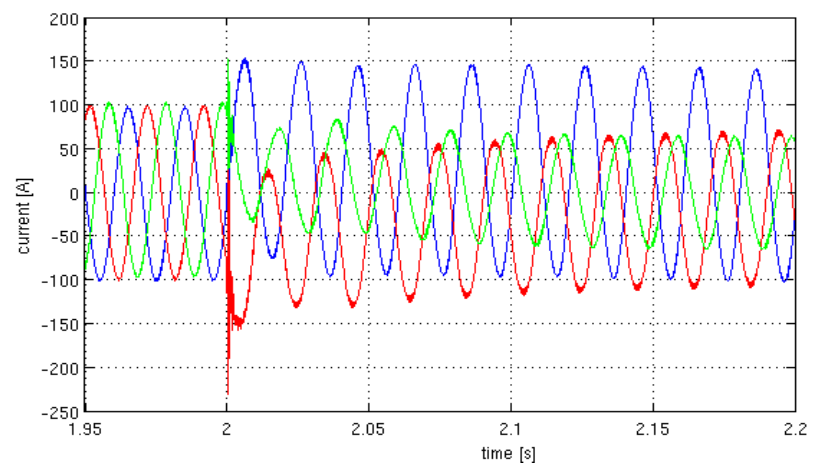

Figure 6. The curve of PV3 Short circuit current

The Fig. 6 shows the time curve of short circuit current of photovoltaic power plant PV3. The increase of current during the fault is not very significant. However, this fault could active the overcurrent protection relay in photovoltaic power plant PV3.

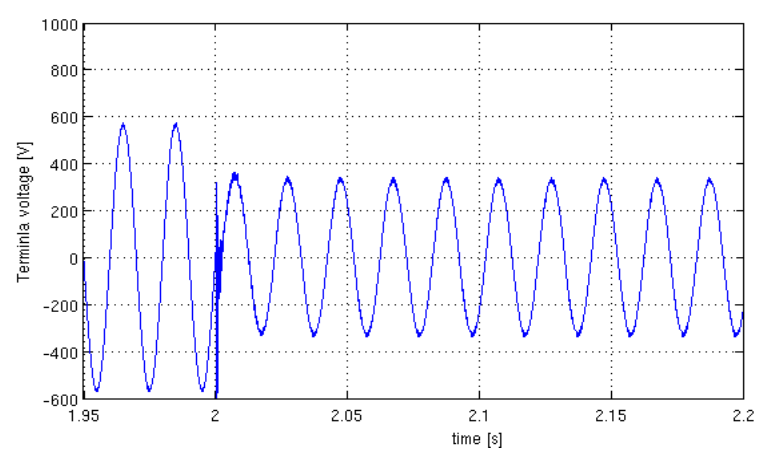

Figure 7. Voltage curve of PV3 
The failure is also identifiable by the voltage decrease (Fig. 7). The size of voltage drop is sufficient to consider the undervoltage protection relay reaction.

Different type of source is the synchronous generator (see CHP in Tab. 2). It generates during fault four times higher current than during the normal operation. Although, the synchronous generator current was much higher than the nominal current of circuit breaker of CHP, it did not achieved instantaneous tripping current of circuit breaker (minimal value of instantaneous tripping current of circuit breaker is $1080 \mathrm{~A}$ ). After disconnection of failed feeder, the synchronous generator lost its synchronism (see Fig. 8) and should be disconnected by protection. As it is also shown in Fig. 8, the lost of synchronism was not caused by the fault itself, but by the base line disconnection. If the fault disappears without base line disconnection, synchronous generator rotor angle deviation obtains initial value, but if base line is disconnected, the rotor angle deviation starts grow unsustainably.

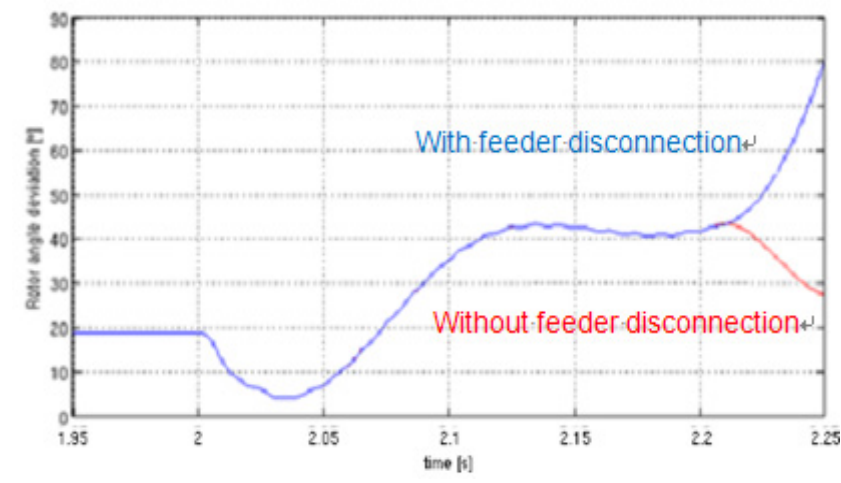

Figure 8. Time chart of synchronous generator rotor angle deviation

In case of simulated type of failure the reaction of protections of all distributed sources can be expected. However the reaction is important (because of the failure of feeding power line), better then the reaction on the failure itself (photovoltaic power plants) is the reaction on the loss of connectivity with superior power system (synchronous generator). This can cause inappropriate disconnection in case of similar fault on different feeder (line V2).

\subsection{Fault on Line V2}

In this case a short circuit occurred on the base line V2 between phases L1 and L2 in 10\% length of base line $(0.905 \mathrm{~km})$. The comparison of nominal current (In), RMS short circuit current of each phase (IkL1 - IkL3) and maximum peak value of short circuit current of each source (photovoltaic $1-4$, cogeneration unit and transformer) and the current in base line V1 is shown in Tab. 2 .

As it is shown in Tab. 3, the currents of photovoltaic power plants during the fault of base line V2 were similar to currents during the fault of base line V1 (shown in Tab. 2).Therefore protective relays of inverters trips in the case of fault on the base line V2.
Table 3. Short circuit currents

\begin{tabular}{|c|c|c|c|c|c|c|c|}
\hline & PV1 & PV2 & PV3 & PV4 & CHP & $\begin{array}{c}\text { Transform } \\
\text { er }\end{array}$ & Line V1 \\
\hline $\mathrm{I}_{\mathrm{N}}[\mathrm{A}]$ & 72.1 & 72.1 & 72.1 & 72.1 & 360 & 3600 & 191 \\
\hline $\mathrm{I}_{\mathrm{kL} 1}[\mathrm{~A}]$ & 87.11 & 87.11 & 87.19 & 87.2 & 720.65 & 4964.8 & 30.52 \\
\hline $\mathrm{I}_{\mathrm{kL} 2}[\mathrm{~A}]$ & 72.51 & 72.5 & 72.54 & 72.61 & 351.71 & 4843.6 & 22.62 \\
\hline $\mathrm{I}_{\mathrm{kL} 3}[\mathrm{~A}]$ & 51.58 & 51.58 & 51.6 & 51.64 & 765.01 & 158.78 & 24.02 \\
\hline $\mathrm{I}_{\mathrm{p}}[\mathrm{A}]$ & $\begin{array}{c}-205.1 \\
1\end{array}$ & $\begin{array}{c}-212.8 \\
8\end{array}$ & $\begin{array}{c}-216.2 \\
0\end{array}$ & $\begin{array}{c}-245.2 \\
5\end{array}$ & 2205.8 & 9402.8 & -85.05 \\
\hline
\end{tabular}

As it is also shown in Tab. 3, the short circuit current of synchronous generator is lower than in the case of V1 failure (shown in Tab. 2). Therefore there is no assumption that the synchronous generator stays connected.

The current in the base line V1 during the failure of base line V2 changed its direction and increased. But it did not achieve its nominal current value and therefore the failure of base line V2 would not cause disconnection of the line V1.

\subsection{Fault at the End of Line V2}

In this case a short circuit occurred at the end of the base line V2 between phases L1 and L2. The comparison of nominal current $\left(I_{n}\right)$, RMS short circuit current of each phase $\left(\mathrm{I}_{\mathrm{kL} 1}-\mathrm{I}_{\mathrm{kL} 3}\right)$ and maximum peak value of short circuit current of each source (photovoltaic $1-4$, cogeneration unit and transformer) and the current in base line V1 is shown in Tab. 3.

Table 4. Short circuit currents

\begin{tabular}{|c|c|c|c|c|c|c|c|}
\hline & PV1 & PV2 & PV3 & PV4 & CHP & $\begin{array}{c}\text { Transform } \\
\text { er }\end{array}$ & Line V1 \\
\hline $\mathrm{I}_{\mathrm{N}}[\mathrm{A}]$ & 72.1 & 72.1 & 72.1 & 72.1 & 360 & 3600 & 191 \\
\hline $\mathrm{I}_{\mathrm{kL} 1}[\mathrm{~A}]$ & 76.5 & 76.5 & 76.5 & 76.5 & 537.8 & 1948.2 & 10.6 \\
\hline $\mathrm{I}_{\mathrm{kL} 2}[\mathrm{~A}]$ & 71.4 & 71.4 & 71.4 & 71.4 & 165 & 1857.6 & 4.3 \\
\hline $\mathrm{I}_{\mathrm{kL} 3}[\mathrm{~A}]$ & 63.6 & 63.6 & 63.6 & 63.6 & 538.9 & 156.5 & 13.6 \\
\hline $\mathrm{I}_{\mathrm{p}}[\mathrm{A}]$ & -131.6 & -133.5 & -137.9 & -147.8 & 1278.3 & 3051.7 & -30.3 \\
\hline
\end{tabular}

As it is shown in Tab. 4, the currents of photovoltaic power plants during the fault at the end of base line V2 were lower than the currents during the faults of previous causes (Tab. 2, Tab. 3). Therefore protective relays of inverters shall not react and photovoltaic power plants stays connected.

As it is also shown in Tab. 3, the short circuit current of synchronous generator is lower than in previous cases (shown in Tab. 2 and Tab. 3). Therefore there is no assumption that the synchronous generator stays connected.

\section{Conclusion}

The growth of distributed generation is expected in the future as a part of smart grid. As the simulation results show, 
the failures on $22 \mathrm{kV}$ feeders could cause the protection relays tripping in photovoltaic power plants. This could cause the loss of significant power in distributed generation. To eliminate this power outage, better coordination of protection relays has to be achieved. This is more relevant with the distributed generation as a substantial part of future smart grids.

Time dependent overcurrent protective relay cannot be used in case of photovoltaic power plants. Overcurrent protective relay set to 1.2 times the nominal current can cause the tripping of photovoltaic protective relay even in case of fault of base line of any feeder.

\section{Acknowledgements}

This work was supported by the agency VEGA MŠVVă̌ SR under Grant No. 1/1045/11 'Integrated Analysis of the Renewable Energy Sources'.

\section{REFERENCES}

[1] C. Gellings, EPRI: Estimating the Costs and Benefits of the Smart Grid: A Preliminary Estimate of the Investments Requirements and the Resultant Benefits of a Fully Functioning Smart Grid, EPRI, 2011

[2] Ai, Q., Wang, X., \& He, X. (2014). The impact of large-scale distributed generation on power grid and microgrids. Renewable Energy, 62, 417-423.

[3] European Commission: Europe 2020 A strategy for smart sustainable and inclusive growth,http://ec.europa.eu/commis sion_2010-2014/president/news/documents/pdf/20100303_1 _en.p.pdf (accessed 19.3.2013)

[4] European Commission: Communication from the Commission to the European Parliament, the Council, the European Economic and Social Committee and the Committee of the Regions: Energy Roadmap 2050, 15.12.2011

[5] Fereidoon P. Sioshansi: Smart Grid : integrating renewable, distributed \& efficient energy, Academic Press, 2012, ISBN 978-0-12-386452-9

[6] Janíček F.: Renewable energy sources 1 Technology for sustainable future. Faculty of Electrical Engineering and Information Technology, Slovak University of Technology, 2009

[7] Soetedjo A., Lomi A., Nakhoda Y. I., Krismanto A. U.: Modeling of Maximum Power Point Tracking Controller for Solar Power System. Telekomnika, Vol.10, No.3, 419-430

[8] Kumar D., Kumar A., Kumar R.: Modeling, Control and Simulation of Integrated Photovoltaic cell-Fuel cell-Battery based Distributed Generation System. UACEE, Vol. 1 No. 2, $68-73$

[9] Robinson, A. P., Blythe, P. T., Bell, M. C., Hübner, Y., \& Hill, G. A. (2013). Analysis of electric vehicle driver recharging demand profiles and subsequent impacts on the carbon content of electric vehicle trips. Energy Policy, 61, 337-348. 